\title{
Assessing the readiness by SMEs and financial institutions in the establishment of an integrated ICT infrastructure for financial transactions in Kenya
}

\author{
Z. Kirori' ${ }^{1}$, M. Achieng ${ }^{2}$ \\ ${ }^{1}$ School of Pure \& Applied Sciences, Karatina University, Karatina, Kenya \\ ${ }^{2}$ School of Business, Jomo Kenyatta University of Agriculture \& Technology, Nairobi, Kenya
}

Email address:

zkirori@gmail.com (Z. Kirori), marimon.ent@gmail.com (M. Achieng)

To cite this article:

Z. Kirori , M. Achieng. Assessing the Readiness by SMEs and Financial Institutions in The Establishment of an Integrated ICT Infrastructure for Financial Transactions in Kenya. International Journal of Intelligent Information Systems Vol. 2, No. 2, 2013, pp. 40-45. doi: 10.11648/j.ijiis.20130202.13

\begin{abstract}
Small and Medium Enterprises (SMEs), mostly in the third world countries face many challenges in the management of finances; namely: the ability to determine daily net earnings after the daily ratios for recurrent monthly deductions such loan premiums and utility bills are made. The main reason is the lack of an elaborate information technology infrastructure that directly targets this vital economic sub-sector for linking it to the general infrastructure that administers other financial transactions. In this article, we report the findings of a research conducted in assessing the readiness of SMEs and the Kenyan financial institutions in the use of information technology to specifically address these challenges.
\end{abstract}

Keywords: Information Technology, Sustainable Entrepreneurship, Financial Institutions, Small and Medium Enterprises

\section{Introduction}

The role of entrepreneurship in economic development in all sectors of the economy cannot be over-emphasized [1]. In her work, "Influence of Managerial Skills on SME's (Small and Medium Enterprises) on the Success and Growth of Small and Medium Enterprises in Kenya", [2], the author states that most small and medium businesses fail within their first three years. Further, in [3], the key speaker in a workshop on SMEs at KICC (Kenyatta International Conference Centre) in Nairobi, noted that lack of managerial training and experience, inadequate education and skills, lack of credit, prohibitive national policy and regulatory environment, technological change, poor infrastructure and scanty markets are the key challenges facing SMEs in Kenya. These have affected their (SMEs) growth and profitability and hence, diminish their (SMEs) ability to contribute effectively to sustainable development.

According to Noel T. and Earnest N, [4], SME's are considered the nucleus of creating new business in any flourishing economy. In a policy brief on financing SMEs and Entrepreneurs, the OECD (Organization for Economic Co-operation and Development) showed that SMEs account for a large share of the private sector economy representing between 96 and 99 per cent of the total number of enterprises in these economies, [5]. However, according to Sanjay Sethi, [6] most SMEs (Small and Medium Enterprises) units get into the weak or sick mode within the first 16 months of operation.

As reported in [7], ICT (Information and Communication Technology) has been the missing link to overcome the challenges faced by SMEs. In this report, the ICT sector has been one of the key contributors to the impressive growth performance in Africa over the last decade. Therefore to sustain this growth momentum, it is imperative that governments - especially in developing countries such as Kenya, besides fostering peace and stability, create an environment that would be conducive to the growth and development of ICT entrepreneurs and nurturing young talents similar to the Silicon Valleys in India, United States, Israel and other countries. By recognizing this economic potential, the governments would be assisting in increasing competitiveness through streamlined administrative procedures, easier access to capital and enhanced capacity to participate in ICT-related projects.

In this recognition, the Kenyan government through the vision 2030 blueprint [8], is in the process of putting in place plans to facilitate economic growth via ICT-led SMEs 
According to the blueprint, Kenya's micro, small and medium businesses are the base of entrepreneurial development and the 'seed bed' for inculcating an entrepreneurial culture and supporting rural industrialization. Further, the innovative document recognizes the crucial role of micro, small and medium businesses in industrial development and emphasizes the development of industrial parks in five towns - Kisumu, Mombasa, Eldoret, Nakuru and Nairobi - to spur industrial growth. It further proposes the development of two special economic zones in Kisumu and Mombasa.

However, the economic blueprint seeks to layout ICT network infrastructure in the manner of high speed and reliable connectivity as opposed to the financial applications to use it. It is therefore the role of financial institutions to work closely with stakeholders in the SME sub-sector to take advantage of this initiative to develop innovative information technology applications that directly target the sub-sector. Financial institutions dedicated to funding SMEs through loans or equity capital are set to play an important role in financing Kenyan entrepreneurs facing high interest rates from commercial banks [4]. In its global study on e-finance (electronic finance) and its role in enhancing the operations and competitiveness of SMEs in meeting their financial obligations, the United Nations in 2001 reported on the potential benefits that internet-based financial transactions can have over traditional methods [9].

\subsection{Problem Formulation}

Many financial institutions in Kenya have discovered the need to step in and bridge this widening gap between SMEs and the ease of access to financial services. However, efforts to this end are largely on mobile-based remote services such as checking of account balances, inter-account transfers and payment of utility bills as opposed to a coherent infrastructure that can handle daily deposits as well as daily remittances. According to separate reports by Micro-Finance Africa and FSD (Financial Sector Deepening) programmes in Kenya, key advances in ICT have mitigated this challenge as ICT has infiltrated the lives and operations of many SMEs in Kenya and beyond $[10,11]$.

Although many Kenyan financial institutions have realized the existence of this gap, few have acted and none has developed a solution for problems that face SMEs in managing their daily revenue.

\subsection{Research Objectives}

The specific objectives of the study were to:

1) Examine the potential benefits brought about by ICT as an interface for SME - bank interaction

2) Assess the role of steadfastness in financial management in instilling financial discipline in SMEs

3) Explore the willingness of financial institutions in implementing unique SME solutions
4) Develop an e-framework through which SMEs can channel their revenue to enhance financial management

5) Suggest the integration mechanisms of the e-framework to existing financial systems

\subsection{Scope of the Study}

This study explores the capacity of ICT as an innovation tool. Five banks and thirty SMEs in Nairobi - Kenya were randomly selected for the study. The sample size and the choice of Nairobi city are justified by the fact that Kenya enjoys less than 10 streamlined banks and Nairobi is the capital city with a cosmopolitan and big population and every other bank has a branch.

\section{Related Work}

In order to better understand challenges facing entrepreneurs, infoDev commissioned a study to assess the current efforts by multilateral institutions and investors in addressing the financing needs of ICT and ICT-enabled SMEs in developing countries [12]. The study identified the key challenges and constraints to meeting these needs as lack of infrastructure, logistics and marketing support.

The European Bank for Reconstruction and Development [13], devised a strategy as a work plan to support MSMEs. The strategy focuses on the core elements of the banks' approach towards supporting the development of MSMEs in its countries of operation. The strategy further aimed to outline how the banks can best support MSMEs across all of the banks' countries of operations, strengthen the financial sector infrastructure dedicated to financing the growth of MSMEs of all sizes, improve the business environment for MSMEs and develop the skill sets of small entrepreneurs.

Richard Duncombe and Richard Heeks [14], presented a research framework for understanding ICT roles across a range of MSMEs. In their findings, they concluded that when considering ICTs for enterprise development in developing countries, ICTs are a great means of SME - bank interaction.

The government of Ghana under its outsourced ITES (IT-enabled industry services) model, commissioned the the development of e-Ghana Project - an ICT-led framework aimed at enhancing the competitiveness and employment levels of Ghanaian MSMEs [15].

Debasish Maitra, a 2nd Year Student at the IRMA (Institute of Rural Management Anand), in India, in his reported research "SME \& Technology-A New Business Metric for Rural" [16], proposed an ICT-motivated architecture to accentuate the togetherness of business and technology. The framework would enable the rural community access to the practical information on small business and timely availability of market information via communication network to help them customize their products and businesses through the potential provided by wireless communications and networking in the rural areas.

In [17], UNIDO (United Nations Industrial Development 
Organization) in partnership with Microsoft Foundation, reported the development of a model aimed at making quality refurbished computers available to SMEs in an economic, environmental and social sustainable manner. The innovative project piloted through Uganda's public-private partnership was meant to address the unmet needs of SMEs in accessing affordable quality PC solutions, thus contributing to their increased productivity, competitiveness and skill transfer.

In Kenya, Equity Bank in conjunction with Telkom Kenya launched an innovative mobile money platform - a versatile product that combines the features of mobile money transfer and mobile banking [18]. Orange money is powered by Equity Bank's mobile banking platform. The money transfer service is mapped onto the customers' bank accounts, making it possible for the customers to literally run their accounts from their mobile handsets, with the accounts' security aligned to that of the bank. This integration allows for the ease of interbank transfers and loan origination using the service for Orange Money customers.

Recently, NIC (National Industrial Credit) bank launched NIC Online, an online banking system that will provide customers with easy access to banking services [19]. NIC Online allows customers to access banking services 24 hours a day in order to upload payments, in line with the bank's strategy to offer customers easy access to its financial services, according to Alan Dodd, corporate banking director, the Internet banking system will allow better cash management for companies and individuals and is part of an expansion strategy that includes the openings of two branches in Thika and Kisumu.

NIC expects the system to considerably lower banking costs, given that it is relatively cheap compared to bank branch charges. Further, an E-payment, which allows corporate and business customers to make lump sum batch transfers, is currently available to customers, and NIC plans to have an e-trade feature before the end of the year to help its customers conduct international trade online.

In mid 2005, Kenya's banking Industry moved a milestone by introducing RTGS (Real Time Gross and Settlement system) which was later renamed KEPSS (Kenya Electronic Payment and Settlement System). The system facilitates the inter-bank financial data transfers thus decongesting banking halls. Digital- based financial services have made a significant contribution in covering the cost of offering financial services.

The banking industry has also over years continued to introduce a wide range of new products, prompted by increased competition, embracing ICT and enhancing customer needs. As a marketing strategy, the new products offered in this segment of market, continue to assume local development brand names to suit the domestic environment and targeting the larger segment of local customer base. Among the products, include Islamic banking which was introduced in 2005, tailored in line with "Shariah" principles. Currently, BBK (Barclays Bank of Kenya), KCB (Kenya Commercial Bank), K-Rep bank and Dubai Bank have so far introduced Islamic banking products in the market.

Like many other developing countries, e-banking in Kenya is at its nascent stages. Not many banks have embraced e-banking but majority have at least one or two technology based delivery channels. The non adoption of e-banking solutions has been attributed to rudimentary technological infrastructure and lack of legislative laws to support e-banking [21].

\section{Research Model}

The research was partially aligned to Rogers' IDT (Innovation Diffusion Theory) [22,23]. According to Rogers, diffusion is the "process by which an innovation is communicated through certain channels over a period of time among the members of a social system". The author also defines innovation as "an idea, practice, or object that is perceived to be new by an individual or other unit of adoption". The model defines five key factors that can influence an individual or individuals to adopt an innovation namely: relative advantage, compatibility, complexity, trialability, and observability.

The study also takes into account the IBSA framework defined by Malek AL-Majali, [22]. IBSA lays out the fundamentals in the use of technology to communicate instructions and receive information from a financial institution where an account is held as well as the enabling system for financial institutions; customers, individuals or business to access accounts transact business, or obtain information on financial products and services through a public or private network". IBSA literature suggests six success factors or constructs for IBSA (perceived ease of use, perceived usefulness, compatibility, trialability, trust, and awareness).

\subsection{Research Design}

In this study, relative advantage (real or perceived) was isolated as the key factor that drives individual and corporate innovation. In his reported work, Rogers describes relative advantage as "the degree to which an innovation is perceived as being better than the idea it supersedes". In other words, it is similar to perceived usefulness.

\section{Research Framework}

The research framework comprised of several factors that commonly contribute towards relative advantage both to the customer as well as the financial institution as shown in figure 1 .

To answer the research questions, a survey was conducted in order to assess the extent of information systems and technology assimilation by banking institutions in meeting the SMEs' financial needs.

\subsection{Data Collection}

The study focused on banks and microfinance companies operating in Nairobi. Using simple random sampling, ap- 
proximately 35 such organizations were selected in Nairobi area.

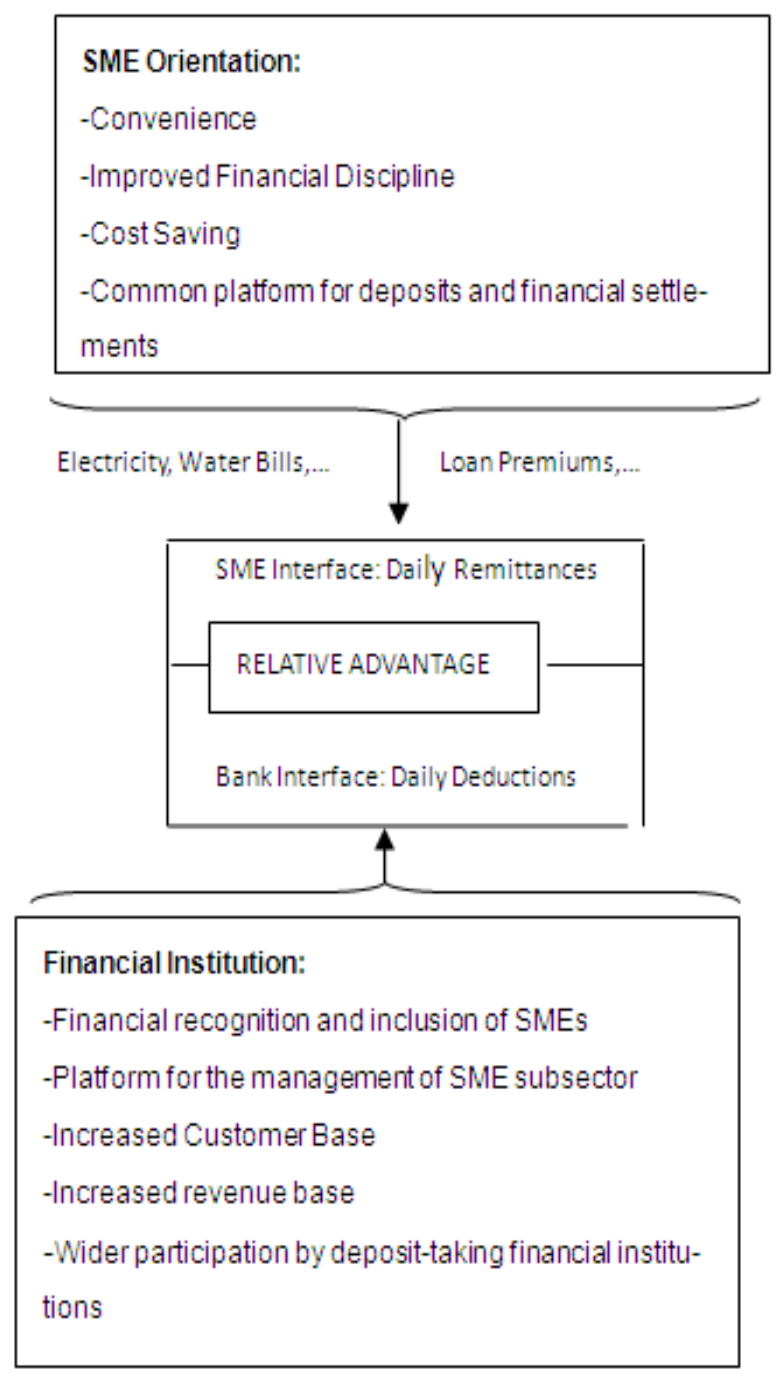

Figure 1. Research Framework

The data was collected by distributing questionnaires to selected banks and SMEs. The SME questionnaire had total 13 questions while the bank questionnaire had 8 questions which the respondents had to answer either yes, no, don't know or provide a short non-categorical response.

\subsection{Pilot Testing}

A pilot test was conducted with a randomly selected sample of three enterprises and this helped establish the validity and reliability of the questionnaire.

\subsection{Data Analysis}

Quantitative data was summarized using descriptive statistics. Qualitative data was derived from reading the responses of the open questions. The data was reviewed, summarized and placed in categories fitting the research questions. Inferences from analyzed data were made and this helped answer the research questions relating to the level of adoption of IT by banks in addressing daily challenges faced by SMEs in Kenya.

Finally the data was analyzed by using Frequency distributions. The technique was used to determine whether the dependent variable (relative advantage) is directly influenced by the independent variables such as convenience and cost saving.

\section{Research Questions}

The following research questions were formulated and subjected to the target population, results collected and analyzed accordingly.

a) Are mobile and internet banking accessible?

b) Can an Online ICT service lead to better financial management?

c) Does ICT reduce banking costs?

d) Can ICT provide a common platform for Deposits and other Financial Settlements?

e) Do you have Unique financial products for SME?

\section{Findings and Discussions}

A sample of 5 questionnaires for the banking institutions and 30 for SMEs were considered and the data arising from the primary research questions analyzed by IBM SPSS V19 for frequency distributions. The analysis of the independent variables with respect to the dependent variable was tabulated in the tables that follow.

Table 1. ICT and Financial Services Accessibility

\begin{tabular}{|c|c|c|c|c|c|}
\hline \multicolumn{6}{|c|}{ Are mobile and internet banking services accessible? } \\
\hline \multirow{5}{*}{ Valid } & & Frequency & Percentage & $\begin{array}{l}\text { Valid } \\
\text { Percentage }\end{array}$ & $\begin{array}{l}\text { Cumulative } \\
\text { Percentage }\end{array}$ \\
\hline & Yes & 19 & 63.3 & 63.3 & 63.3 \\
\hline & No & 4 & 13.3 & 13.3 & 76.7 \\
\hline & $\begin{array}{l}\text { Don't } \\
\text { know }\end{array}$ & 7 & 23.3 & 23.3 & 100.0 \\
\hline & Total & 30 & 100.0 & 100.0 & \\
\hline
\end{tabular}

Table 2. ICT and Financial Discipline

\begin{tabular}{|c|c|c|c|c|c|}
\hline \multicolumn{6}{|c|}{ Can an Online ICT service lead to better financial management? } \\
\hline \multirow{5}{*}{ Valid } & & Frequency & Percentage & $\begin{array}{l}\text { Valid } \\
\text { Percent }\end{array}$ & $\begin{array}{l}\text { Cumulative } \\
\text { Percentage }\end{array}$ \\
\hline & Yes & 21 & 70.0 & 70.0 & 70.0 \\
\hline & No & 4 & 13.3 & 13.3 & 83.3 \\
\hline & $\begin{array}{l}\text { Dont } \\
\text { know }\end{array}$ & 5 & 16.7 & 16.7 & 100.0 \\
\hline & Total & 30 & 100.0 & 100.0 & \\
\hline
\end{tabular}

Table 3.ICT and Cost Saving

\begin{tabular}{|c|c|c|c|c|c|}
\hline \multicolumn{6}{|c|}{ Does ICT reduce banking costs? } \\
\hline \multirow{5}{*}{ Valid } & & Frequency & Percentage & $\begin{array}{l}\text { Valid } \\
\text { Percentage }\end{array}$ & $\begin{array}{l}\text { Cumulative } \\
\text { Percentage }\end{array}$ \\
\hline & Yes & 23 & 76.7 & 76.7 & 76.7 \\
\hline & No & 2 & 6.7 & 6.7 & 83.3 \\
\hline & $\begin{array}{l}\text { Not } \\
\text { sure }\end{array}$ & 5 & 16.7 & 16.7 & \multirow[t]{2}{*}{100.0} \\
\hline & Total & 30 & 100.0 & 100.0 & \\
\hline
\end{tabular}


Table 4. ICT and Integrated Platform

\begin{tabular}{|c|c|c|c|c|c|}
\hline \multicolumn{6}{|c|}{$\begin{array}{l}\text { Can ICT provide a common platform for Deposits and other Financial } \\
\text { Settlements? }\end{array}$} \\
\hline \multirow{4}{*}{ Valid } & \multirow{3}{*}{$\begin{array}{l}\text { Yes } \\
\text { Dont } \\
\text { know }\end{array}$} & \multirow{2}{*}{$\begin{array}{l}\text { Frequenc } \\
\mathrm{y} \\
27\end{array}$} & \multirow{2}{*}{$\begin{array}{l}\text { Percentag } \\
\text { e } \\
90.0\end{array}$} & \multirow{2}{*}{$\begin{array}{l}\text { Valid } \\
\text { Percenta } \\
\text { ge } \\
90.0\end{array}$} & \multirow{2}{*}{$\begin{array}{l}\text { Cumulative } \\
\text { Percentage } \\
90.0\end{array}$} \\
\hline & & & & & \\
\hline & & 3 & 10.0 & 10.0 & 100.0 \\
\hline & Total & 30 & 100.0 & 100.0 & \\
\hline
\end{tabular}

Table 5. ICT Products that target SMEs

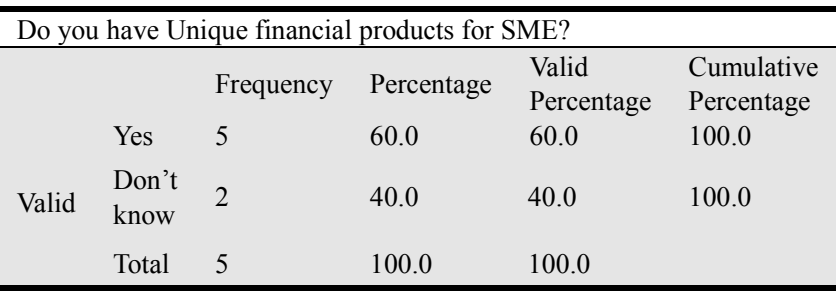

Table 6. Summary of the results of the eight questions assumed

\begin{tabular}{|c|c|c|c|c|}
\hline Questions & $\begin{array}{l}\% \\
+ \text { ves } \\
\text { (Yes) }\end{array}$ & $\begin{array}{l}\% \\
\text {-ves } \\
\text { (No) }\end{array}$ & $\begin{array}{l}\% \\
\text { Other }\end{array}$ & Result \\
\hline $\begin{array}{l}\text { Are mobile and internet } \\
\text { banking } \\
\text { accessible? }\end{array}$ & 63.3 & 13.3 & 23.3 & Possibly yes \\
\hline $\begin{array}{l}\text { Can an Online ICT service } \\
\text { lead to better financial } \\
\text { management? }\end{array}$ & 70.0 & 13.3 & 16.7 & Yes \\
\hline $\begin{array}{l}\text { Does ICT reduce banking } \\
\text { costs? }\end{array}$ & 76.7 & 6.7 & 16.7 & Majorly yes \\
\hline $\begin{array}{l}\text { Can ICT provide a } \\
\text { common platform for } \\
\text { Deposits and other } \\
\text { Financial Settlements? }\end{array}$ & 90.0 & 0.0 & 10.0 & Yes it does \\
\hline $\begin{array}{l}\text { Do you have Unique } \\
\text { financial products for } \\
\text { SME? }\end{array}$ & 80.0 & 20.0 & 0.0 & Yes it does \\
\hline
\end{tabular}

\section{Conclusion}

Considering that the questionnaire was pilot tested for validity and reliability, the analysis of the Quantitative data using descriptive statistics and presented using tables and percentages showed that the questions were acceptable. The system can actually be a convenient medium to enhance interaction between SME's and banks.

A steadfast Information Technology infrastructure can therefore enhance access to financial facilities by SMEs. It will provide a common platform for deposits and financial settlements to boost their financial management and eventually reduce banking costs for SMEs.

The findings of this research established that SMEs do indeed face challenges in managing their finances and would greatly welcome a bank-led solution to overcome them. It is true that SMEs not only contribute significantly to improve living standards, employment generation and poverty reduction but they also bring about substantial domestic or local capital formation and achieve high levels of productivity and capability in developed and developing countries.

\section{Recommendations}

The findings of this research point to two main causative factors as to why SMEs are performing below standard. One relates to banking habits and the other is poor management of funds. Therefore banks should develop an ICT solution through which SMEs can channel their daily earnings to enhance financial management. SME's require a system that can reduce their costs in terms of time and interest charges. Daily deductions of monthly commitments such as rent and other utilities can free the SMEs to concentrate on the business while capturing the financial institutions through conviction that their loan and bill settlements are automatic.

From these findings, it is recommended that the banking and the micro-finance sectors in Kenya work together to develop appropriate information technology infrastructure that will help ease the burden of managing their (SMEs) revenue and expenditure. Indeed, this model can be replicated elsewhere in the developing nations where similar challenges exist.

The SME sub-sector can certainly be an effective tool for a rapid industrialization of an economy as long as it is backed by adequate financing and effective use of information technology in management.

\section{References}

[1] Urve Venesaar and Piret Loomets. (2006). The Role of Entrepreneurship in Economic Development and Implications for SME Policy in Estonia. 14th Nordic Conference on Small Business Research, Stockholm, Sweden.

[2] Marion Mbogo. (2011). Influence of Managerial Accounting Skills on SME's on the Success and Growth of Small and Medium Enterprises in Kenya. Journal of Language, Technology \& Entrepreneurship in Africa Vol. 3 (1)

[3] Challenges Facing SMEs in Kenya. Workshop held at KICC (2012).

[4] Noel Tagoe, Ernest Nyarko, Ebenezer Anuwa-Amarh. (2005) Financial Challenges Facing Urban SMEs under Financial Sector Liberalization in Ghana. Journal of Small Business Management, Vol. (43)

[5] Organization for Economic Co-operation and Development Policy Brief (2006). Accessed from: http://www.oecd.org/dataoecd/53/27/37704120.pdf. Date: $13 / 03 / 2011$

[6] Sanjay Sethi. (2011). micro, small and medium enterprises, government of Maharashtra, India. Financial times.

[7] Winifred Ambunya. (2012). Equity funds court. SMEs fleeing high interest rates.

[8] Vision 2030. Flagship projects. Accessed from: http://www.vision2030.go.ke/index.php/pillars/project/Econ omic/39. Date: $16 / 5 / 2011$

[9] Making business loans a reality for micro and small enterprises in Kenya. Report by USAID Kenya (2010). 
[10] Mobile money takes East Africa by storm. A report by micro-finance Africa (2012).

[11] Branchless Banking. A report by FSD-Kenya. (2009).

[12] Scaling Up ICT-Enabled Innovation \& Entrepreneurship in Developing Countries: The Role of Private Sector Finance. Accessed from: http://www.infodev.org/en/Project.28.html. Date: $21 / 04 / 2011$

[13] Micro, Small and Medium-Sized Enterprises Strategy. Document of the European Bank for Reconstruction and Development. (2006)

[14] Richard Duncombe and Richard Heeks (2005). Information \& Communication Technologies (ICTs), Poverty Reduction and Micro, Small \& Medium-scale Enterprises (MSMEs). A framework for understanding ICT applications for MSMEs in developing countries

[15] IT-Enabling Services (ITES) Industry Support Sub-Component. An ICT-based SME model by GoG. Retrieved from: http://www.ites.gov.gh/IT-Industry.aspx. Date: $01 / 12 / 2011$

[16] Debasish Maitra.(2010). SME \& Technology-A New Busi- ness Metric

[17] Promoting Public-Private Partnerships: An innovative business model to foster pro-poor growth through Information and Communication Technology (ICT). UNIDO-Microsoft report (2008)

[18] Roberto Zavatta. (2008). Financing Technology Enterpreneurs \& SMES in Developing Countries: Challenges and Opportunities. An infoDev publication

[19] Rebecca Wanjiku. (2008). Kenyan bank launches online banking. IDG News Service, Nairobi Bureau.

[20] Richard Nyangosi. (2008). E-Banking: An Integration Technology in Kenya.

[21] Isaac Awuondo. (2006). e-Banking in Kenya: Practical lessons to be drawn

[22] Malek AL-Majali. (2011). Modeling the antecedents of internet banking service adoption (IBSA) in Jordan: A Structural Equation Modeling (SEM) approach

[23] Azyanee Luqman. (2011). E-business Adoption amongst SMEs: A Structural Equation Modeling Approach. Journal of Internet Banking and Commerce. vol. 16 (2) 